\title{
A NEWLY DISCOVERED \\ MANUSCRIPT OF THE POEMA MORALE.
}

\section{INTRODUCTION.}

$\S$ 1. In November 1904 the Fitzwilliam Museum, Cambridge, received a valuable bequest of manuscripts, books and objects of art from the late Frank McClean M. A., F.R.S., F.R. A.S. etc. of Trinity College, Cambridge, and Tunbridge Wells. In a MS. of this Collection, the so-called Nuneaton Codex, now MS. McClean 123, I found a hitherto unknown copy of the Poema Morale.

§ 2. $\mathrm{MS}, 123(=\mathrm{M})$ is a small folio written on vellum by a French scribe, $167 \mathrm{~mm}$. $\times 262 \mathrm{~mm}$, and bound in the original marocco-covered boards.

$\S 3$. The contents of the MS. is briefly as follows: -

(1) ff. $1-7$ b [T]ractatus in lingua romana secundum dominum Robertum Grosseteste lincholiensem episcopum de principio creacionis mundi,

beg. qui bien pence ben puet dire

ends La uerge sun creatur

811 lines in two columns.

(2) ff. $7^{b}-9^{a}$ Prose-treatise on the Pater Noster,

beg. pres ceo devez sauer quels sunt ...

ends vus serra done tut sanz demander. Amen.

229 lines in two columns.

f. $9^{b}$ blank.

(3) ff. $10^{\mathrm{a}}-27^{\mathrm{b}}$ The Gospel of Nichodemus,

beg. $\mathrm{Nz}$ le honor de la trinite

ends Deu le me otrie le fiz marie. Amen.

2193 ll. in two columns.

ff. 28,29 blank.

Anglis. N. F. XVill, 
(4) ff. $30^{\mathrm{a}}-65^{\mathrm{b}}$ Bestiary of William le Trouvers

with thirty seven outline drawings.

beg. QVi ben comence e ben define

ends e lur iugement attendrunt. Amen.

4200 ll. in two columns.

(5) ff. $66^{a}-105^{a}$ The Apocalypse in Latin and French, edited in Romania XXV. $17 \mathrm{ff}$.

f. $105^{\text {b }}$ blank.

(6) ff. $106-107$ a Officium beate uirginis

with music on a five-line staff.

ff. $107^{\mathrm{b}}-108$ blank.

(7) f. 109 a Seint Austin escrist cest orcisun,

beg. Deus propicius esto

ends In nomine patris et filii et spiriti sancti. Amen.

25 lines.

f. $109^{\text {b }}$ blank.

(8) ff. $110^{a}-113^{a}$ Treatise on the Pater Noster,

beg. Apres ceo deuez sauer

e nds par sa seynte contemplacion

329 11. in 2 columns.

ff. $113^{\mathrm{b}}, 114^{\text {s }}$ blank.

(9) f. $114^{\mathrm{b}}$ The names of the symbols $p p j \cdot 2$

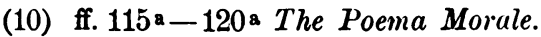

337 lines.

ff. 121, 122 fly-leaves.

$\S 4$. The MS. has been noticed by Paul Meyer in his edition of the 'Version Anglo-Normande de l'Apocalypse', Rom. $\mathrm{XXV}, 180 \mathrm{f}$. (1896), but curiously enough he altogether omits to mention the Poema Morale which no doubt accounts for its having remained unknown up to the present date.

$\S 5$. M. Meyer gives the date of the MS. as 'vers l'an 1300 '; Dr. Montague James places it similarly 'about 1300 , perhaps a little earlier'. This date refers to $\mathrm{n}^{\text {os }} 1,3,6,9,10$, the remaining parts are in a somewhat later hand.

$\S 6$. The MS. was in the XV century in the possession of the convent of Nuneaton, Warwickshire, cf. f. 9 'Iste liber' constat domine Margarete Sylemoun et disciplas suas. Et post mortem suam couentu de NunEtoun' ( $1 / 2$ XV cent.); f. 1 'Iste liber constat Alicia Scheyntoun and per ea conventu' ( $\mathrm{xv}$ century). Another owner was 'John Eyton Kt' (xvi century) f. $113^{b}$, and according to a pencil-note on $f .1$ the volume 
was a 'Gift of $M^{\mathrm{r} s}$ Lacy to John Gibson, 8 Oct. 1853'. It afterwards came into the possession of Quaritch, the wellknown Piccadilly bookseller, who in his order sold it to Mr. McClean.

$\S 7$. The poem is written in long lines, 32 lines to the page. The initial letter of each line is somewhat larger and slightly separated from the rest of the line, and as a rule faintly touched with red. The coloured initials intended to stand at the head of the poem and of its subdivisions, have, however, not been inserted, but they are as usual indicated by letters of a smaller size in the margin. Spaces for these initials occur at ll. 1, (3), 21, 33, 99, 149, 207 as indicated in the text.

It is notewortly that the scribe uses the Anglo-Saxon $p$ for $u u(w)$. That the specifically English signs $b, p, z, \mathfrak{\imath}$. were unfamiliar to him is shown by his noting them down on the page facing the first page of the poem, clearly for the sake of easy reference.

$\S 8$. The dialect of $M$ is Kentish with a strong intermixture of more westerly forms as can be seen from the following characteristics. Cf. Morsbach, Me. Gram. §§ 9, 132.

(1) OE. $y, \dot{y}$ appears (a) as $c$ in ageltep 279, beip 140, euel(e) 19, 26, 59, 87, 98, 115 (twice), 122, 164 (twice), 215, felle 310 , uellep 278, felp 277 , forgelt 286 , ileste 212 , kenne 321 , kennes 78, mankenne 292, 300, lefte 77, misdede (pt. pl.) 95, nele 117, 283, 298, nelle 147, neste 96, 211, 232, netep 223, senne 123, 274, 291, sennes 226, senezede 244, 261, unwenne 192, vnhed 153.

(b) as $u$ in agultep 194, agult 11, 87, gult 158, gulte 199, gultes 256, 284, gultep 85, bugge 61, dude 2, 181, 193, 249, 251, 253, 318, misdude 93, hulle 309, kunne 184, sunne 183, $186,191,282$, fur $72,235,237$. M. has further muchel throughout, which, however, is probably, to be explained from OE. *mučel, cf. Morsbach, op. cit $\S \S 130$. a. 4, 133. a. 2.

(c) as $i(y)$ in pinche 46 , pinchep 221, pincp 314, ofpincp 126, mankinne 271, yuerrede 98. 
The porportion of the forms with $e: u: i(y)$ is therefore as $40: 26: 6$.

The $e$-forms proponderate in the rhymes, viz.

$e: e \quad$ lefte (OE. lyft) : scefte (OE. sceaft) 77-8.

It is noteworthy that $M$ is the only MS. where this rhyme is pure, cf. T 83-4 lofte: safte, J lufte : schafte, L lifte : scefte, D seafte : lefte, E lofte : scefte, e lufte : sceafte.

neste : ileste 212-3.

$u$ : e sunne : unwenne 191-2, hulle : felle 309-10.

$i$ :e mankinne : senne 271-2.

$u: u$ sunne : kunne 183-4.

(2) The WS. breaking ea, éa before $1+$ cons. appears as $i e$, initially $z e$ in hielde (OE. healdan) : chielde $217-8$, zelde (0E. eald) : bihielde 265-6, zelde : selde 43-4, zelde : yhelde 278-8 but $52-3$.

eld 6, eldi 4, yhelde (inf.) 278, welde (inf.) : ihelde (part.)

(3) OE. éa appears before non-palatals as $i e, \delta e-$ in lien (0E. léan) 58, zedi (0E. éadiz) 213， zep-lete (0E. éabe) 70, 144, 243.

(4) OE. initial $h w$ appears as $h u$, $h w$ in huat 88, 232, huiche 132, huile 226, hwo 320, elsewhere as wh.

(5) OE. $f$ initially before a vowel and in the combinations $f l, f r$ has as a rule become $u(v)$ e.g. vele 11,192 , uorzet 25 , ule 146, uram 98, 220 (twice). The proportion of $f: u(v)=$ $22: 64$.

$\S 9$. The two first lines of the text printed below form no part of the Poema Morale, they are in fact merely the first stanza of the sermonizing poem Sinners Beware, printed in An Old English Miscellany (EETS. Orig. Ser. no. 49), p. 72. Cf. Brandl in Paul's Grd. ${ }^{2}$ II $\S 13$.

The probable explanation is that both poems occurred in the original from which our present text was copied, and that by some oversight on the part of the scribe he began to transcribe the wrong poem and subsequently made no 
attempt to correct his mistake. In VS. 29 Jesus College, Oxford, for instance, the Poema Morale is immediately followed by 'Synners Beware', see EETS. no. 49, pp. 58, 72.

It is, of course, also possible to assume that the lines were placed as a suitable 'motto' at the head of the poem.

Relation of $M$ to the remaining MSS. of the Poema Morale.

$\S 10$. Six MSS. of the Moral Ode were previously, known, viz.

(1) $\mathrm{D}=$ MS. Digby. A. 4, Bodleian Library, Oxford, partly printed by Hickes in his Thesaurus I 222 , edited by Zupitza, Anglia I $5 \mathrm{ff}$. It differs from all others in being written in short-lined stanzas.

(2) $\mathrm{E}=$ MS. Egerton 613, ff. 7-12", edited by Furnivall Early English Poems and Lives of Saints (Phil. Soc. Trans. 1858), by Morris Old English Homilies, First Series, II, 288-295, and 175-183 (EETS. no. 34).

(3) $\mathrm{e}=$ VSS. Egerton 613 , ff. $64-70^{\mathrm{b}}$, practically the same text as $\mathrm{E}$ but in a different hand. Printed in Zupitza's Altenglisches Übungsbuch.

(4) J = MS. 29 Jesus College, Oxford, ff. 242-247 now deposited in the Bodleian, printed by Morris $A n$ Old English Miscellany pp. 58-71 (EE'TS. 49), reprinted by him in Specimens of Early English, $2^{\text {nd }}$ ed., p. $194 \mathrm{ff}$.

(5) $\mathrm{L}=$ MIS. Lambeth 487 , ff. $59^{\mathrm{L}}-65^{\text {a }}$, printed by Morris in Old Engl. Homilies, First Series, II, 159-175 (EETS. no. 34). 'This MS. contains the first 270 lines alone.

(6) ' $\mathrm{T}$ ' = MS. 'Trinity College, Cambridge, B. 14.52, ff. 2-10, printed by Morris Old Engl. Homilies, Second Series, 220-232 (EETS. no. 53) 1873, reprinted in his Specimens, p. $195 \mathrm{ff}$. 
A critical edition of the poem has been published by Hermann Lewin, Das Mittelenglische Poema Morale, Halle 1881. Cf. Engl. Stud. V 409, Anglia IV, Anz. 88, Egge, Mod. Lang. Notes 1887, no. 1, col. 14 .

$\S 11$. Concerning the dates of the above MSS. Zupitza (Anglia I $5 \mathrm{f}$.) places D at the beginning of the XIII century, for the dating of the others he quotes the opinion of Wanley and the respective editors, whose statements I find, however, to be in some need of correction.

No date at all is assigned to $\mathrm{E}$ by either Furnivall or Morris, and concerning e Furnivall merely refers to it as a later copy. Lewin says concerning $\mathrm{E}$ and $\mathrm{e}$. 'Beide dürften im anfange des 13. jhdts. entstanden sein.'

The experts of the British Museum Dr. Warner and Mr. J. A. Herbert, who have kindly given me their opinion on this point, assign both $\mathrm{E}$ and $\mathrm{e}$ to the XIII century and hold $\mathrm{e}$ to be the earlier of the two, and neither of them to be written especially early in the XIII century.

MS. J Morris (EETS. no. 53 p. viii) states to have been written 'about 1246-1250'. It is, however, possible to give a more accurate date, for which I am indebted to Mr. E. W. B. Nicholson, the Bodley Librarian. He writes concerning MS. J, 'From f. 217 to the end of the volume is apparently all in one hand, and was certainly written about the same time. It contains a history of Tobias which mentions the then Prior of St. Mary. Kenilworth (Gwilleyme): this fixes the date of composition at 1276-9, and I believe that to be approximately the date of the writing'.

The same late date would consequently also be assigned to the remaining poems printed by Morris in An Old English Miscellany pp. 37-57, 72-191 from our MS. J. fol. 217 ff., viz. from f. 217-242 The Passion of our Lord, f. 248 Sinners Beware, f. $251^{\mathrm{b}}$ ff. The Woman of Samaria, A Lnue Ron, and various other minor poems, f. 262 The Proverbs of Alfred, f. $271 \mathrm{ff}$. The XI Pains of Hell and other short religious poems. 
T Wanley places 'circa tempora Henrici II ant Ricardi I' (Catal. p. 169), that is, between 1154 and 1199; Morris holds that it is later than $\mathrm{L}$ but older than $J$ (EETS. $53 \mathrm{p}$. viii note); Zupitza (op. cit. p. 6) that is was probably written not long after 1200. Dr. Montague James in his Catalogue of the Western MSS. in Trinity College, Cambridge, places $\mathrm{T}$ in the XIII century, and he has further specified this statement by assigning it to the early years of the century in question, thus confirming Zupitza's view.

$\mathrm{L}$ is placed by Wanley p. 266 in the reign of Richard I (1187-99); Morris (EETS., 53, p. vir) holds it to be older than T. Dr. Montague James, who has kindly given me his opinion on the subject, considers it to be late XII or early XIII century, thus confirming Wanley's and Morris's opinions.

$\S 12$. The relationship of these MSS. has been established by Zupitza in his above-mentioned edition of D (Anglia I $32 \mathrm{ff}$.) in the following way: -

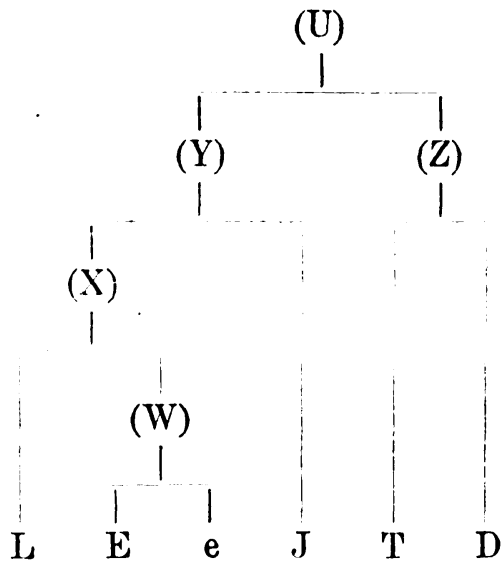

A comparison between $\mathrm{M}$ and these previously known MSS. shows that it does not agree with (U) as represendet by $(\mathrm{Y})$ or $(Z)$ but must have descended from a different original: -

(a) In the characteristic readings which differentiate ( $Y$ ) and $(\mathrm{Z}), \mathrm{M}$ agrees twice with $(\mathrm{Z})(\mathrm{ll} .18,295)$, five times with 
(Y) (ll. 34, 58, 241, 257), in one case with neither (1. 71); in the remaining seven cases noted by Zupitza the corresponding lines are missing. (Cf. Anglia I 32.)

Z

(D) 9, 3 mai

" 17,3 for

" 30, 3 workes

\ 36,2 ful

"37, 1 no ping uorhole

" 66, 2 on orer

77, 4 hidden

125, 1 lease men

128, 3 men

" 135, 1 attliche

" 135, 4 engles

"143, 1 and

" 144, 3 vor naht hi solden bidde per

n 156, 2 wir purste

"160, 1 were
$\mathrm{Y}$

michte

om.

swinches

swa

noht forholen uihud

enne dei orer

wruzen

lease

sonde

laøliche

on hevene

om.

for nis noper imne helle

wid chele wid purst

we were
$\mathrm{M}$

1. $18 \mathrm{mai}$

"34 om.

„58 suinches

$" 71$ wel

stanza om.

line om.

1. 241 "lese

stanza om.

1. 257 lodlich

"258 in heuene stanza $o m$.

1. 295 were

(b) M has four lines which do not occur in (U) viz. $97-8$ :

'Iesu Crist, seinte Marie sone, us alle helpe \& rede, '\& eueremore yscilde us, uram euele yuerrede.

and 217-18:

'pe hadde pis worldes ezte, \& faste gunne hielde,

' $\&$ hi nolde helpe par, of pe hungri ne pe chielde.

Of these $97-8$, occurring at the end of a section, strongly suggest the ordinary colophon of the pious scribe, and are probably spurious, but as for $217-8$ there seems no reason to doubt their originality.

(c) The order of lines in $\mathrm{M}$ differs widely from that observed in the MSS. of (U), as can be seen by a glance at the text, where the figures in italics to the right of the text represent the order of lines in ' $\mathrm{T}$, which is followed with few exceptions by all the other MSS.

The reason for these curious deviations from the usual order can of course only be conjectured. They can scarcely 
be put down to the copyist; he would no doubt have found it easier to go straight on than systematically to reverse the order of his original. Considering the great popularity of the Poema Morale it is far more likely that the immediate original of our text, or at all events a copy not far removed from it, was taken down from memory. This would also account for the fact that not less than seventy lines are missing of the ordinary number found for instance in $\mathrm{T}$, viz. ll. $13,14,27,28,57,58,76,77,80,117,118,151,152,155$, $156,169,170,183,184,197,198,203,204,207,208,255,256$, $265,266,277,278,289,290,293-302,325,326,327,330,331$, $332,369-379,382,387-392,394-6$ of MS. T. It might also account for the addition of the first stanza of 'Sinners Beware' (cf. $\S 9$ ), and for a very considerable number of verbal changes introduced, e. g.

\section{88 Huat sculle we come to dome}

T $94 \mathrm{Hwat}$ sulle we seggen orer don

M 124 To longe he abit, pat suo abit, to bidde Cristes ore.

$\mathrm{T} 130$ For-pi he is sot pe swo abit to habben godes ore

II 13 pat siggep pe, pat were par, \& wite hit mid iwisse.

$\mathrm{T} 141$ pat habbep isaid pe come panne pit wiste mid iwisse.

M 136 nor ore nihte blisse.

$\mathrm{T} 142$ for sene nihte blisse.

M $139 \&$ so hi bep of pe dere

$\mathrm{T} 145$ swo is of wilde diere

M 152 his workes \& his dede.

T 160 his word and ec his dade.

II $172 \mathrm{Ne}$ brecp neuere eft Iesus helle for ham, to bringe ham ut of bende.

T 182 Brecð nafre eft Crist helle dure for [to] lesen hem of bende.

M 174 Himself he polede dep for us, wel dere he us bozte

T 186 Him self he polede dead for hem wel diere he hes bohte.

M 175-6 Half-lines transposed

M 210 \& ze hit habbep ihurd rede.

$\mathrm{T} 228$ par me hit mai rede. 
$\S 13$. From the above it is apparent that the ultimate original of $\mathrm{M}$ can hardly have been (U); we therefore assume it to have been (V), in which case (U) and (V) must have had a common source (S). Zupitza's pedigree of the MSS. (see $\S 12$ ) would therefore be carried one step further back and assume the following shape: -

(S)

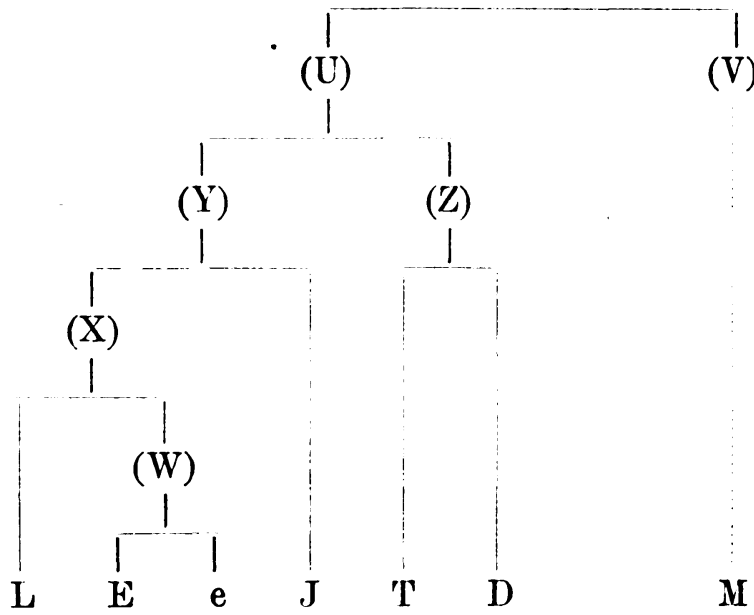

Of the intervening links between $M$ and $(V)$ nothing can be said with certainty beyond the fact that they must have been numerous, possibly orally transmitted, in order to produce the many variations from the prototype which is more closely preserved in the MSS. of group (U). 


\section{TEXT.}

f. 115a pe holi gostes mizte, us alle helpe \& dizte, us wissie \&

us teche,

Y-scilde us fram pe unwizte, bi daie \& bi nizte, pat penchep us bipeche.

Ich am elder pane ich was of wintre \& of lore;

Ich eldi more pane ich dude, mi wit azte beo pe more.

5 To longe ich habbe child ibeo, of wordes \& of dede;

pez ich beo of wintres eld, to zung ich am of rede.

Vnnet lif ich habbe ilad \& zet me pincp ich lede;

Whane ich me bipenche wel, sore ich me a-drede.

Mest what pat ich habbe ido is idelnes \& chilse;

10 To late ich habbe me bipozt, bute me Crist do milse.

Vele idele wordes ich habbe ispeke, sippe ich speke cupe.

$\&$ fele zunge dede ido, \& pat me rewep nupe.

Al to muchel ich habbe a-gult, of wrke \& of worde;

Al to muchel ich habbe ispend, to litel ileid on horde. 12

15 Ich mizte bet habbe ido, zef ich hadde pe selpe,

$\mathrm{Nu}$ ich wolde, \& ich ne mai, for elde ne for unhelpe.

Elde me is istolen up-on, er pan ich hit wiste.

pat ich ne mai me iseo bifore, uor smiche ne for miste.

Arz we beop to donne god, of euel al to priste,

20 More eie stondep man of man, pane him do of Criste. 20

pe wel ne dep pe while he mai, sore hit scal him rewe,

Whane hi sculle mowe \& ripe, her pat hi er sewe.

Dop al to gode pat ze muze, pe while ze bep aliue;

Ne truste noman to muchel, to childe ne to wiue.

25 Man pat hine selue uorzet uor wiue oper uor childe, He scal come in euele stede, bute god him beo milde. 26

1) The figures in italics on the right side of the text indicate the corresponding lines of $\mathrm{T}$.

In printing the text I have followed the usual principles, viz. (a) Contractions and abbreviations have been expanded, the letters supplied being printed in italics. (b) Brackets have been used to denote the addition of a word or a letter, the original reading being in every case given in the foot-notes. (c) Proper names have been indicated by capitals, whereas in the MS. they are written with small letters except when standing at the beginning of a line. (d) The punctation is my own. (e) All other deviations from the MS. have been carefully noted in the foot-notes. 
Ne beo pe leuere pane pi self, pi mei ne pi moze;

Sot is pat is opre mannes frend betere pane his oze.

Ne truste wif to hure were, ne were to his wiue;

30 Biuore him do wel euerich man, pe while he is aliue.

Vor he is ${ }^{1}$ ) wis, pat hine bipanch, pe while pat he mot

libbe,

So sone wllep hine uorzete pe uremde $\&$ pe sibbe.

f.115b pe wel ne dep pe whil he mai, ne scal he whane he') 35

wolde;

Manies mannes sor yswinch habbeb ofte unholde.

35 Ne scolde noman don auirst, ne sclakie wel to done;

Vor mani man bihotep wel, \& hit forzet wel sone.

Ac pilke man pat wle beo siker to habbe godes blisse,

Do wel himself pe while he mai, panne havep he mid $t 0$

ywisse.

pis riche men wenep beo siker purz walles \& purz diche;

40 Ac pe dep his ezte in sikere stede, he hit sent to

heueneriche.

Vor par ne darf he ben afered of fure ne of peue,

par ne mai hit him binime pe lope ne pe leue.

par ne darf he habbe care of zunge ne of zelde.

pider we sendep \& us self berep to litel \& to selde. $\quad 46$

45 pider ze scolde alle don, wolde ze me yleue;

par ne mizte hit us binime king ne no scerreue.

pider we scolde bere \& draze, ofte $\&$ wel ylome;

par ne mizte me hit us binime mid none wronge dome. 48

Al pat faireste pat man hauep, to gode he hit scolde 51 sende;

50 par he hit mizte finde eft, \& habbe euere bute ende. 52 pe man pe his ezte wel wile wite, pe while he mai welde, $5 \tilde{5}$ Jeue he uor godes loue, panne bep hi wel ihelde. 56 pe man pat ani god dop her uor habbe godes ore, 53 par he hit scal finde eft an hundredfelde more.

55 pe man pat dep her mest to gode \& alpre lest to lope, 61 Aiper to litel \& to muchel hit scal him pinche bope, Whane me scal ure wurkes weze to uore pe heuenkinge, $\&$ zeue us ure suinches lien after ure erni[n]gge. ${ }^{2}$ )

1) above the line in the original scribe's hand.

2) Ms. ernigge. 
Ne scal non euel beo unbozt ne no god unzulde;

60 Euel we dop al to muchel, god lasse pane we scolde. 60 Ac euerich man mid pan pe he hauep, mai bugge godes 6.5 riche;

pe pe more hauep \& pe pat lasse, bope iliche.

Ase wel p'on mid his penie, alse pe oper mid his punde

(bis is pat alpre beste ware, pat euere was ifunde);

.116a $65 \&$ pe pat ne mai namore do, mid is gode ponke

Also wel so he pat hauep of goldes fele monke.

Vor ofte god kan more ponc him pat him zefp lasse,

Jef his workes \& his wezes is milse \& riztwisnesse.

Litel loc is gode lef, pat cump of gode wille,

$70 \&$ zep-lete muchel zeue of him pat his herte is ille.

Heuene \& erpe he ouersiep: his ezene bep wel brizte, 75

Sonne \& mone, sterre \& fur is pestre to-zenes his lizte. (om $\mathrm{T})$

He wot \& walt what dop \& quepep, alle quike wizte. $\tau_{8}$

Nis no louerd, suich is Crist, no king suich is ure drizte. 79

75 Heuene \& erpe god almizti halt al in his honde.

He dep al pat his wille is, a watere \& a londe.

He scuppep pe fish in pe seo, pe fozel bi pe lefte.

He wot alle kennes ping, he scop alle scefte.

$\&$ he is ord bute ord, $\&$ ende bute ende.

$80 \mathrm{He}$ is one in eueriche stede, wende whider pu wende

$\mathrm{He}$ is boue \& he is binepe, biuore \& bihinde;

pe man pat godeswille dep, oueral he hine mai finde.

Eche rune god ihurp, god wot ache dede;

He purzsiep aches mannes ponc. What scal us to rede? 90

85 We pat brekep godes $\mathrm{i}[\mathrm{h}]$ est 1$) \&$ gultep suo ylome,

What sculle we sigge oper do atte heze dome?

We pat her habbep agult, \& euel lif her ladde,

Huat sculle we come to dome, par angles bep adradde?

What sculle we bere us biuore, mid wham sculle we 95

yqueme,

90 We pat non god ne habbeb ydo pe heuenliche deme?

par sculle beo deueles suo fele, \& wullep us forwreie;

Ne habbep hi noping forzete, her pat hy yseze.

Al pat we misdude her, hi hit us wllep cupe pare

Bute we hit habbe her ibet, pe while pat we her were. 100

1) Ms. isest. 
$95 \mathrm{Al} \mathrm{hi} \mathrm{habbep} \mathrm{in} \mathrm{hure} \mathrm{write,} \mathrm{pat} \mathrm{we} \mathrm{misdede} \mathrm{here;} \mathrm{101(T)}$ pez we hi neste ne ${ }^{\prime}$ ) iseze, hi were ure yfere. 102

f.116b Iesu Crist seinte Marie sone us alle helpe \& rede, (om T) \& eueremore yscilde us, uram euele yuerrede. $\quad($ om $\mathrm{T})$

100 Awi, so fele beop icliped, so uewe beop ycorene.

What sculle horlinges do, pe suike \& pe forsuorene? 103 A wi, what scolde hi bizete, what scolde hi yborene, pat sculle beo to depe ydo, \& eueremore uorlorene? Ac euerich man him selue scal bic[1]ipie $\left.{ }^{2}\right) \&$ eke deme, $\mathrm{Al}$ his workes $\&$ his pozt par to he scal teme.

105 Euerich man him selue scal deme to d[e]ape ${ }^{3}$ ) oper 11: to liue.

pe witnesse of his workes, to oper pan him scal driue. 116 Nis no witnesse al so muchel, so is pe mannes herte; 113 pe man pat saip pat he is lame, himself he wot pe smerte. 114 $\mathrm{Ne}$ mai no man deme pane man also rizte;

110 Not non his workes so wel, so wot ure drizte.

Euerich man himself wot best his workes $\&$ his wille:

Ac pe pat wot lest saip ofte mest, \& pe pat al wot is stille. 112 Ac Crist ne demep nanne man after his ginni[n]gge, $\left.{ }^{4}\right) 119$ Ac al scal beo his lif iteld, suich is his endingge.

115 Jef his ende is euel al, hit is euel, \& god, zef god beop his ende.

Iesu Crist leue pat ure ende beo god, \& witie pat he us lende.

Ac pe pat nele neuere no god do, ne god lif her lede, Ere dep \& dome come to his dore, sore he mai adrede, pat he ne muze panne bidde ore, uor pat itit ilome.

Vor-pi he is wis pat ore bit, $\&$ bet biuore dome.

Vor whane dep \& dome comep to his dore, to late he biddep ore,

To late he letep euele workes, pat ne may hi do namore.

Whane senne let pe, \& pu nazt hi, \& pu ne mizt do namore;

To longe he abit, pat suo abit, to bidde Cristes ore.

125 Ac napeles we hit ileuep, uor drizten self hit sede:

Of whiche time pat man ofpincp his misdede,

Oper raper oper later, milse he scal ymete;

1) Ms. ne ne.

L biclepie, E bi-clepiean.
श) Ms. bichipie; DTe biclepien, J bi-cleopien, 8) Ms. drape.
4) M. ginnigge. 
Ac who-so noping her nauep ibet, muchel he hauep to bete.

f.117a Ac mani man saip, 'Who recp of pine, pat scal habbe 135(T) ende?

130 Ne recche ich, beo ich a domesdai ilesed ut of bende'. 0 , lite wot he what is pine, \& lite pine he knowep, Huiche pine pe soule polep, hu biter wind par blowep. Vor hadde he par ibeo, tuo bare tide, Vor al pat gold of midelerd, pe pridde he nolde abide. 140

135 pat siggep pe, pat were par, \& wite hit mid iwisse:

Wo wrpe pe sorze of seuezer, uor ore nizte blisse.

Vor ore blisse pat ende hauep, endeles pine:

Betere is wori wateres drinch, pane atter ime[n]gd 1) mid wine.

Suines brede bep wel suete, \& so hi bep of pe dere;

$140 \mathrm{Al}$ to dere he hi beip, pat zefp par-uor his suere.

Vul wombe mai liztliche speke of hunger \& of uaste; Suo mai of pine pat not, what hie is, pat euere scal ilaste. Hadde he yfonded one stunde, he wolde sigge a-noper; Jep-lete him were wif \& child, suster vader \& broper 150

145 Eueremore her in wo, \& in pine wonie, 153

Wip pan pe he mizte helle pine ule $\&$ ysconie.

Vor of pat pine pat par beop, nelle ich zo noping leze. 291 Nis hit bute game \& gleo her pat pat flesh mai dreze 292 Of pe dome we ${ }^{2}$ ) wllep speke, of whan ich 30 er $15 \%$ seide,

150 At pan daie \& pan dome, Crist us helpe $\&$ rede. par we muze beo afered, \& harde us adrede;

par euerich man ysiep biuore his workes \& his dede. 160 Al scal beo par vnhed, her pat we hele, ${ }^{3}$ )

Al scal beo par unwrize, her pat man luze \& stele.

155 par we sculle aches mannes lif iknowe ase ure $0 z$ e. par sculle eueni[n]gges ${ }^{4}$ ) beo pe heze $\&$ pe loze.

Ne scal him nazt scamie par, ne darf he him adrede, 165 He pe ofpuzte her his gult, \& bette his misdede.

\footnotetext{
1) Ms. imegd.

2) ich, crossed out, precedes.

3) Ms. unhele, with un crossed through and expunged.

4) Ms. euenigges.
} 
Him ne scamep ne him ne gramep, pat scal beo i-boreze;

160 Ac pe opre habbep scame \& grame \& opre fele soreze. $168(\mathrm{~T})$

f. $117 \mathrm{~b}$

Al pat euere ysprungen is of Adam \& of Eue,

To pe dome hi sculle come, forsop, ze hit yleue.

Hi sculle habbe hardne dom, pat her were harde,

pe euele helde poure men \& euele laze arerde.

165 Euerich after pan pe he hauep ido, he scal par beo ydemed.

Welle blipe mai he beo, pat gode her hauep iquemed.

po pat gode iserued habbep, after hare mizte,

Hi sculle to heueneriche fare, uorp mid ure drizte.

pe opre pat pe deueles worc habbep ido, \& par inne beop ifunde,

$170 \mathrm{Hi}$ sculle falle adun mid him into hel[1] $\mathrm{e}^{2}$ ) grunde.

$\&$ pare hi sculle wonie eueremore bute ende;

Ne brecp neuere eft Iesus helle for ham, to bringe ham 182 ut of bende.

Enes ure louerd helle brac, his frend he ut brozte;

175 Nolde hit fader do for pe sune, ne suster uor pe broper, 188

$\mathrm{Ne}$ hit moze uor pe mei, ne noman uor oper.

Vnnepe we zeuep for his loue a stecche of ure brede; 191

Lite we penchep pat he scal deme, pe quickewe \& pe dede. 192

Vre louerd uor his preles, ipined was on pe rode.

180 Vre bendes he unbond, \& bozte us mid his blode.

Muchel he dude for ure loue, zef we hit wolde understonde. 193

Ac pat pe ure eldringes misdede, we hit habbep wel 194 harde on honde. ${ }^{1}$ )

$\&$ lite penchep ani man, hu lite was pe sunne, purz whan we poliep alle dep, pe come of Adammes 206 kunne.

185 Dep com in pis midelerd purz pes deueles onde;

Sunne \& soreze \& i-suinch ${ }^{3}$ ), a watere \& a londe.

purst \& hunger, chele $\&$ hete, eche $\&$ unhelpe, 200

purz dep com in pis midelerd, \& manie opre unselpe.

Elles nere no man died, ne sike ne unsele,

190 Ac mizte libbe eueremore in blisse $\&$ in hele.

Adam \& his offspreng uor ore bare sunne

1) above the line.

2) Ms. hele.

s) Ms. in suinch. 
Were uele hundred wintre in helle pine $\&$ in unwenne.212(T)

$\&$ suppe god dude so muchel wreche $\left.{ }^{1}\right)$ uor ore misdede, 209

We, pat so ylome \& ofte agultep her, wel sore we maie 210

$$
\text { a-drede. }
$$

$195 \&$ pe pat ledep hare lif mid werre \& mid y-wronge,

Bute hit godes milse do, hi sculle beo par wel longe.

Godes wisdom is wel muchel \& so bep his mizte;

Nis his mizte no lasse pane was po bi pan ilke wizte.

More he one mai uorzeue, pane al uolk gulte kunne;

200 pe selue deuel mizte habbe milse, zef he hit hadde bigunne.

pe man pe godes milse isecp, iwis he hit scal finde;

Ac helle king is oreles wip pan pat he mai binde.

pe pat dep his wille best, wrst he hauep mede:

His bap scal beo wallinde pich, his bed berninde glede.

205 Wrst he dep ${ }^{2}$ ) his godewines, pane his fulle uende.

Iesu Crist us iscilde alle fram suiche euele frende.

Neuere in helle ich ne com, ne neuere come ne recche, 225

paz ich al pes worldes wele, par inne ${ }^{3}$ ) wende uecche.

Ac pez ich wlle zo telle, ase wise men me seide,

$210 \&$ on boc hit is iwrite, \& ze hit habbep ihurd rede.

$\&$ ich hit wlle telle us, pat hit er neste,

$\&$ warni us wip unureme, zef ze me wllep ileste.

Vnderstondep nu to me, zedi men \& areze ${ }^{4}$ ),

$\&$ ich ou wille telle of helle pine, \& warni us wip harme.

215 In helle is hunger \& purst, wel euele tuo inere;

pos pine sculle polie par, pat were nipinges here,

pe hadde pis worldes ezte, \& faste gunne hielde,

$\&$ hi nolde helpe par, of pe hungri ne pe chielde.

par is woninge \& wop in eueriche strete,

$220 \mathrm{Hi}$ uarep uram hete to pe chele, uram chele to pe hete.

Whane hi beop in hete, pe chele ham pinchep blisse;

Whane hi beop in pe chele, of par hete hi habbep misse. 238

Netep hi neuere whaper ham dop wrs, to neuere none 240

Aiper ham dop wo inoz, ne habbep hi none lisse.

ywisse;

f. 118b $225 \mathrm{Hi}$ walkep enere \& sechep reste, ac hi ne muze ymete, 241

Vor pan pe lii nolde pe huile hi mizte hure sennes bete.

1) above the line. erasure of one letter $m$ (?).

Anglia. N. w. Xvilr.
9) he dep twice.

4) arme in the other Mss.
3) inne preceded by 
Hi sechep reste par non nis, \& hi ne muze non par finde; Ac walkep weri vp \& dun, suo water dop mid pe winde. pos beop pe pat were her of ponke unstedeuaste,

230 pe pe bihete Iesu Crist, \& nolde him ylaste,

pe pat god wrc bigunne, \& fulendi hit nolde, \& were her \& while par, \& neste huat hi wolde.

par is pat pich pat euere walp, pat sculle pe beo inne, pe pat ladde hure lif, mid werre \& mid ywinne.

235 par is pat fur pat is hundredfelde hatter pane vre:

Not hit noper aquenche, Auene strem ne Sture.

pat is pat fur pat euere barnp, pat noping ne mot aquenche.

pe sculle beo inne pe were lef poure men to suenche, 254 $\&$ pe pe louede reuing \& stale \& unmetliche drunke,

$240 \&$ ec in pes deueles work suo blepeliche swonke;

pe pe were so lese, pat me ne mizte ham yleue,

Med-zerne domesman \& wrongewise reue;

pe pe was opre mannes wiues lef, his ozen zep-lete, $\&$ senezede blupeliche on drunke \& on ete;

245 pe pat poure men binome \& leide in hare horde, $\&$ litel lete of godes hest \& of godes worde;

pe pe were ze[t]seres ${ }^{1}$ ) of pisse world $e[z]$ te $^{2}$ ),

$\&$ dude al pat pe lope gost hem tizte do \& tezte;

pe pe was opre mannes god leuere pane him scolde,

$250 \&$ were al to gredi of selure \& of golde;

$\&$ vnriz $[t]$ wisnesse ${ }^{3}$ ) dude par hi scolde beo holde,

Lete what hi scolde do, \& dude pat hi ne scolde;

pe pat in alle wise pe deuele her iquemde,

po beop in helle mid him uor-done \& nordemde,

255 Bute pe pat o[f]puzte 4) sore hure misdede,

$\&$ hure gultes gunne bete $\&$ betere lif lede.

f.119a par beop lodlich fend in stronge raketeze,

pos beop pe pat were mid gode in heuene swipe heze.

par beop grisliche fend \& aterliche wizte,

260 pe sculle pe wrecche saule iseo, pat senezede mid isizte. 286

Neuere sunne par ne scinp ne mone ne sturre,

Euere par is muchel godes hate \& muchel godes erre. 280 Euere par is muchel smich \& pusternesse \& eie,

1) Mr. zeseres.

8) Ms. unrizwisnesse.
9) Ms. este; aihte $\mathrm{TJ}$, echte $\mathrm{LEe}$, ezte $\mathrm{D}$.

4) Ms. of puzte. 
Ne com par neuere oper lizt, pane of pe suarte leye. 282(T)

265 par is pe lope Sathanas \& Belzebuc pe zelde,

Welle sore hi muze ben afered, pat suiche sculle bihielde. 288

Scilde him euerich man wip be helle pine,

Warni euerich man his frend, \& suo ich wille do mine.

$\&$ pe pat scilde ham ne cunne, pis ham wile teche, 305

270 is word may aiper, zef hi sculle, beo lichames \& saule leche.

Lete we pat god forbet alle mankinne;

Do we pat god us het \& werie us wip senne.

Louie god mid herte $\&$ mid al ure mizte.

$\&$ vre nexte al suo us self, suo us het ure drizte.

310

$275 \mathrm{Al}$ pat me redep \& sincp biuore godes borde,

Al hit hongep \& halt bi pe ilke tuam worde.

$\&$ alle godes laze he felp, pe niwe laze \& pe zelde,

pe pis laze uellep \& can hi wel yhelde.

Ac strong hie is to yhelde, so ofte we ageltep alle;

315

280 Strong hit is to stonde longe \& lizt hit is to falle.

Ac Crist us zeue his mizte, stonde pat we mote,

$\&$ of alle ure sunne, leue us come to bote.

We wilniep after worldes wel, pat lange nele ileste.

$\&$ leggep muchel ure suinch, in ping unstedeuaste.

285 Suonke we uor godes loue, alse we dop uor ezte,

Nere we noping suo ofte forgelt ne bi[k]ezte. 1)

$\&$ zef we seruede gode, alsuo we dop ermi[n]gges, ${ }^{2}$ )

We mizte in heuene habbe al so muche ase erles oper 324

kinges.

f. 119b Vor almizti godes loue, wute we us werie,

290 Wip pe wrecche worldes wele, pat hie us ne derie.

Mid almesse, mid ibede, werie us wip senne,

Mid pe wepne pat god almizti bitezte alle mankenne. 340

We scolde us bipenche, ofte \& wel ylome, 328

What we bep, to whan we sculle, \& whar of we come; 329

$295 \mathrm{Jef}[\mathrm{we}]^{3}$ ) were wisemen, pus we scolde penche,

3.33

$\&$ bute we wrpe us iwar, pe norld us wle adrenche.

1) Ms. bipezte (?) the third letter being more like a $p$ than anything else. bi-keihte $\mathrm{T}$, bikazte $\mathrm{D}$, bicauhte $\mathrm{Ee}$, by-pouhte $\mathrm{J}$.

2) Ms. ermigges.

s) $\mathrm{EeJ}$. 
Mest manne hie zeuep drinch of one duole scenche;

He scal him cunne scilde wel, zef hie him nele screnche.336(T)

Lete we pe brode strete $\&$ pane wei bene,

300 pat let pat nizende del to helle of mankenne \& mor ase 1)

ich wene.

Nime we pane narewe pap \& pane wey grene,

par forp farb wel litel folc, \& pat is pe worlde on-sene.

pe brode stret is ure wil, he is us lop to lete;

pe pat folzep al hare wil, hi farep mid pe ilke strete.

$305 \mathrm{Hi}$ muze liztliche go mid par niper-helde

purzut pe godlese wode in to pe bare felde.

pe narewe pap is godes heste, ac pare uorp uarep wel uewe;

$\&$ pis beop pe pat scildep ham her wip euerich unpewe. 350 pos gop azenes pe heze clif, azenes pe heze hulle,

$310 \mathrm{Hi}$ letep al hure oze wil godes hesne to felle.

Go we alle in pilke pap, \& he us wule bringe

Mid pe uewe uaire men biuore pe heuenkinge.

par is blissene mest mid anglene songe,

pe pat is uele hundred wintre par, ne pincp hit hi nazt 356 longe.

315 Mai non hunger ne no wane beo in godesriche, 359

par beop wonie[n]gges ${ }^{2}$ ) fele \& ech oper unliche.

Sum par hauep lasse murcpe \& sum par hauep more;

Euere after pat pat he dude ${ }^{3}$ ) her, of pat pe he bisuanc 362 sore.

$\&$ pe pat hauep lest, he ${ }^{4}$ ) hauep suo muche, pat he ne 357 bit nammore;

320 Hwo se let pe blisse uor pes, hit scal him rewe sore. 358

f. 120a Ne scal par beo noper bred ne win, ne opre kenne este; 363 God scal beo eueriches lif, blisse, \& eke reste.

Ne scal par beo noper foz ne grei, cunig ne ermine, 365 0-kerne ne martrin, beuer ne sabeline.

325 Ne scal par beo noper schat ne scrud, ne worldes wele none, Al pe blisse pat me us bihot, al hit scal beo god one. 368 God is suo mer \& suo muchel in his godnesse,

1) Ms. past; mo ich wene $\mathrm{JDEe}$, me mai wene T. ') Ms. woniegges.
8) Ms. ḅ dude.
4) Ms. he he. 
A NEWLY DISCOVERED MANUSCRIPT OF THE POEMA MORALE. 237

pat he mai \& wule beo anglene blisse.

$380(\mathrm{~T})$

Ac pez ne beop ure ezene alle iliche brizte.

$330 \mathrm{He}$ in pis worlde nere nazt alle of one mizte, 383

par ne sculle nazt habbe god al mid one wizte.

Hi sculle more of him wite pe louede hine more, $\&$ biknowe \& byseo his milse \& his ore.

To pare blisse us bringe god pat ricsclep ay bute ende, 397 335 Whane he ure saule unbint of lichamliche bende.

Crist us leue lede suich lif \& habbe suicchne ende, pat we mote to him come, whane we henne wende.

400

Amen.

Newnham College, Cambridge.

Anna C. Paues. 